\title{
The Transmembrane Domain of Synaptobrevin Influences Neurotransmitter Flux through Synaptic Fusion Pores
}

\author{
Chung-Wei Chiang, ${ }^{1,2}$ Che-Wei Chang, ${ }^{1,3}$ and $\odot$ Meyer B. Jackson ${ }^{1,2,3}$ \\ ${ }^{1}$ Department of Neuroscience, ${ }^{2}$ Biophysics Graduate Training Program, and ${ }^{3}$ Physiology Graduate Training Program, University of Wisconsin-Madison, \\ Madison, Wisconsin 53705
}

The soluble $N$-ethylmaleimide-sensitive factor attachment receptor (SNARE) proteins synaptobrevin (Syb), syntaxin, and SNAP-25 function in $\mathrm{Ca}^{2+}$-triggered exocytosis in both endocrine cells and neurons. The transmembrane domains (TMDs) of Syb and syntaxin span the vesicle and plasma membrane, respectively, and influence flux through fusion pores in endocrine cells as well as fusion pores formed during SNARE-mediated fusion of reconstituted membranes. These results support a model for exocytosis in which SNARE TMDs form the initial fusion pore. The present study sought to test this model in synaptic terminals. Patch-clamp recordings of miniature EPSCs (mEPSCs) were used to probe fusion pore properties in cultured hippocampal neurons from mice of both sexes. Mutants harboring tryptophan at four different sites in the Syb TMD reduced the rate-of-rise of mEPSCs. A computer model that simulates glutamate diffusion and receptor activation kinetics could account for this reduction in mEPSC rise rate by slowing the flux of glutamate through synaptic fusion pores. TMD mutations introducing positive charge also reduced the mEPSC rise rate, but negatively charged residues and glycine, which should have done the opposite, had no effect. The sensitivity of mEPSCs to pharmacological blockade of receptor desensitization was enhanced by a mutation that slowed the mEPSC rate-of-rise, suggesting that the mutation prolonged the residence of glutamate in the synaptic cleft. The same four Syb TMD residues found here to influence synaptic release were found previously to influence endocrine release, leading us to propose that a similar TMD-lined fusion pore functions widely in $\mathrm{Ca}^{2+}$-triggered exocytosis in mammalian cells.

Key words: exocytosis; neurosecretion; synapse; synaptobrevin

Significance Statement

SNARE proteins function broadly in biological membrane fusion. Evidence from non-neuronal systems suggests that SNARE proteins initiate fusion by forming a fusion pore lined by transmembrane domains, but this model has not yet been tested in synapses. The present study addressed this question by testing mutations in the synaptic vesicle SNARE synaptobrevin for an influence on the rise rate of miniature synaptic currents. These results indicate that synaptobrevin's transmembrane domain interacts with glutamate as it passes through the fusion pore. The sites in synaptobrevin that influence this flux are identical to those shown previously to influence flux through endocrine fusion pores. Thus, SNARE transmembrane domains may function in the fusion pores of $\mathrm{Ca}^{2+}$-triggered exocytosis of both neurotransmitters and hormones.

\section{Introduction}

Neurons release neurotransmitter by calcium-triggered exocytosis of synaptic vesicles, and this process depends on soluble

\footnotetext{
Received March 19, 2018; revised June 22, 2018; accepted June 30, 2018.

Author contributions: C.-W. Chiang wrote the first draft of the paper; C.-W. Chiang, C.-W. Chang, and M.B.J. edited the paper; C.-W. Chiang, C.-W. Chang, and M.B.J. designed research; C.-W. Chiang and C.-W. Chang performed research; C.-W. Chiang analyzed data.

This work was supported by NIH Grant NS044057. We thank Laurence Trussell, John Bekkers, and Edwin Chapman for help comments and suggestions on this paper, and Chen Ji for help with the immunofluorescence.

The authors declare no competing financial interests.

Correspondence should be addressed to Dr. Meyer B. Jackson, Department of Neuroscience, University of Wisconsin-Madison, 5505 WIMR II, 1111 Highland Avenue, Madison, WI 53705. E-mail: Meyer.Jackson@Wisc.edu.

C.-W. Chang's present address: Gladstone Institute, University of California, San Francisco, CA 94107.
}

$N$-ethylmaleimide-sensitive factor attachment receptor (SNARE) proteins. The vesicle SNARE synaptobrevin 2 (Syb2) associates with the plasma membrane SNAREs syntaxin and SNAP-25 to form a tight $\alpha$-helical bundle (Jahn and Scheller, 2006; Jahn and Fasshauer, 2012), and the N- to C-terminal zipping of these proteins as they assemble into the SNARE complex is thought to provide energy to overcome intermembrane repulsion, deform lipid bilayers, and drive the fusion of the two membranes. While regulated exocytosis requires SNARE proteins, questions remain as to the generality of the mechanisms used by this large family of 
membrane-trafficking proteins. Work in endocrine cells (Xu et al., 1999; Sørensen et al., 2006), synapses (Hua and Charlton, 1999), and reconstituted membranes (Melia et al., 2002; Pobbati et al., 2006; Gao et al., 2012) suggests that SNARE complex zipping is a common feature of SNARE-mediated fusion. However, even the fastest exocytosis in reconstituted systems is much slower than $\mathrm{Ca}^{2+}$-triggered exocytosis in cells. Compared with dense-core vesicles, small clear vesicles such as those at synapses fuse with very different kinetics (Verhage et al., 1991; Ninomiya et al., 1997; Liu et al., 2011), and form fusion pores with different characteristics (Bruns and Jahn, 1995; Klyachko and Jackson, 2002).

Syb2 and syntaxin have C-terminal transmembrane domains (TMDs) in which mutations alter the flux through fusion pores in endocrine cells (X. Han et al., 2004; X. Han and Jackson, 2005; Chang et al., 2015; Dhara et al., 2016) and reconstituted lipid membranes (Bao et al., 2016). These results support a model for fusion that begins with the formation of a gap junction-like, TMD-lined pore that spans the plasma and vesicle membranes (Lindau and Almers, 1995; Chang et al., 2017). Although TMDs are essential for the full function of SNAREs in exocytosis (Chang et al., 2016), lipid-anchored SNAREs lacking TMDs can in some cases support fusion of proteoliposomes and yeast vacuoles (McNew et al., 2000; Jun et al., 2007; Xu et al., 2011). The minimal number of SNARE complexes needed for fusion may be too small to surround a pore (Mohrmann et al., 2010; Sinha et al., 2011; Shi et al., 2012), but in other contexts the numbers may be higher (Montecucco et al., 2005; Domanska et al., 2009). A purely proteinaceous pore cannot explain the flux of lipid label in advance of aqueous label (Zhao et al., 2016). Although proteinaceous versus lipidic fusion pores are widely viewed as mutually exclusive, composite models containing both can be envisioned (Chang et al., 2017).

The sensitivity of flux to TMD mutations serves as a useful criterion for assessing the role of proteins in fusion pores. This test has been applied to endocrine cells and reconstituted systems but currently available techniques do not provide a robust, direct measure of flux through synaptic fusion pores. Theoretical work suggests that the fusion pore controls the time course of neurotransmitter release, which in turn should influence the shape of unitary synaptic currents produced by a single vesicle (Khanin et al., 1994; Clements, 1996; Stiles et al., 1996; Wahl et al., 1996; Chang et al., 2017). We therefore used miniature excitatory postsynaptic currents (mEPSCs) as a probe of flux through synaptic fusion pores. Patch-clamp recordings of mEPSCs from cultured hippocampal neurons were analyzed to evaluate the kinetics of release mediated by mutants of Syb2 harboring different amino acid substitutions in the TMD. We identified four TMD residues that influenced mEPSCs in a manner consistent with a role in synaptic fusion pores. The same four Syb2 TMD residues had been identified previously as fusion pore liners in chromaffin cell dense-core vesicle exocytosis (Chang et al., 2015). This suggests that the Syb2 TMD plays a similar role in $\mathrm{Ca}^{2+}$-triggered exocytosis in both synapses and endocrine cells. Thus, exocytosis in these two systems may be initiated by the formation of a fusion pore with a similar composition and structure.

\section{Materials and Methods}

Hippocampal neuron culture. Syb2/cellubrevin double knock-out (DKO) neurons were obtained by crossing Syb $2^{+/-} /$cellubrevin $^{-/-}$mice and taking the Syb2 ${ }^{-1-} /$ cellubrevin $^{-1-}$ homozygotic E17.5-E18.5 embryos of either sex to prepare primary hippocampal neuron cultures (Guzman et al., 2010). The dissected hippocampus was dissociated with $0.05 \%$ (w/v) trypsin-EDTA and plated onto $12 \mathrm{~mm}$ coverslips coated with 0.2 $\mathrm{mg} / \mathrm{ml}$ poly-D-lysine (in borate buffer, $\mathrm{pH}$ 8.5). Neurons were grown at $37^{\circ} \mathrm{C}$ in a $5 \% \mathrm{CO}_{2}$-air atmosphere in neurobasal-A-based culture medium supplemented with GlutaMAX, B27, and ampicillin/streptomycin. AraC $(1.5 \mu \mathrm{M})$ was added after $3 \mathrm{~d}$ in vitro (DIV) to reduce glial cell growth.

Lentiviral infection. Lentiviral expression vectors encoding full-length wild-type-Syb2 (WT-Syb2) and Syb2 TMD mutants were generated as described previously (Chang et al., 2015). All double amino acid substitutions were performed with the QuikChange II site direct mutagenesis kit (Agilent Technology). Lentivirus was packaged in HEK 293T cells by cotransfection with two viral packaging plasmids VSVG and $\Delta 8.9$ using the calcium phosphate method. Medium with virus was collected 48-72 $\mathrm{h}$ after transfection and concentrated by centrifugation at $70,000 \times g$ for $2.5 \mathrm{~h}$. Neurons were infected after 5-7 DIV by directly adding virus to the culture medium. All mutants were tested in $\geq 20$ cells from $\geq 4$ embryos and $\geq 3$ litters.

Immunocytochemistry and imaging. Littermate and DKO hippocampal neurons expressing WT or mutant Syb2 were fixed with 4\% paraformaldehyde, permeabilized, blocked with $0.1 \%$ Triton X-100/3\% goat serum $/ 2 \%$ bovine serum albumin, and incubated with mouse anti-Syb2 (104211, Synaptic Systems) and guinea pig anti-synaptophysin 1 (101004, Synaptic System) antibodies at $4^{\circ} \mathrm{C}$ overnight. Samples were treated with goat anti-mouse and goat anti-guinea pig secondary antibody conjugated respectively with cy 2 and cy 3 for $45 \mathrm{~min}$ at room temperature. Fluorescence images were acquired using a $100 \times$ oil objective on a Nikon Ti-E Eclipse inverted microscope with a Neo-sCMOS camera controlled through NIS-Elements AR software. Lasers emitting 488 and $561 \mathrm{~nm}$ light were used for excitation with intensity set at 10 and 5\%, respectively, for all images. Puncta intensity and synapse density were measured in MATLAB 2015b (MathWorks) with SynD (Schmitz et al., 2011). Colocalization was evaluated with Fiji ImageJ software.

Whole-cell patch-clamp. Whole-cell patch-clamp recording was performed with an EPC 7 amplifier (HEKA) controlled by pClamp software (Molecular Devices). Coverslips with neurons at 14-19 DIV were transferred to $35 \mathrm{~mm}$ dishes with extracellular solution composed of the following (in mM): $140 \mathrm{NaCl}, 5 \mathrm{KCl}, 5 \mathrm{CaCl}_{2}, 1 \mathrm{MgCl}_{2}, 10$ HEPES, and 10 glucose, $\mathrm{pH} 7.4$, at room temperature. NMDA receptors, GABA receptors, and action potentials were blocked with $50 \mu \mathrm{M}$ APV, $10 \mu \mathrm{M}$ SR95531, and $0.5 \mu \mathrm{M}$ tetrodotoxin, respectively. Aniracetam (2 mM) was added to the extracellular solution for the indicated experiments. Sylgard-coated patch pipets were filled with intracellular solution containing the following (in $\mathrm{mm}$ ): $120 \mathrm{Cs}$-gluconate, $8 \mathrm{CsCl}, 2 \mathrm{NaCl}, 10$ EGTA, 5 phosphocreatine, 5 HEPES, $2 \mathrm{Mg}$-ATP, and $0.3 \mathrm{Na}-\mathrm{GTP}$. Patch pipettes filled with this solution had resistances of 3-8 M $\Omega$. Membrane potential was held at $-70 \mathrm{mV}$ throughout recordings. Series resistance determined by balancing the charging transient was generally $\sim 10 \mathrm{M} \Omega$; cells were discarded when series resistance exceeded $30 \mathrm{M} \Omega$. Cell capacitance was $\sim 12 \mathrm{pF}$ so that typical voltage-clamp settling times were $\sim 120$ $\mu$ s. Current responses were filtered at $3 \mathrm{kHz}$ and digitized at $50 \mathrm{kHz}$. Up to four $1 \mathrm{~min}$ gap-free recordings were performed for each cell.

Experimental design and statistical analysis. Raw traces were imported into IGOR Pro (WaveMetrics) and analyzed with a custom computer program that detected mEPSCs automatically using a template scanning method (Clements and Bekkers, 1997). The criterion for detecting mEPSCs as set in the program identified $98 \%$ of the events when compared with manual inspection of sample records from eight cells transfected with WT-Syb2 and a Syb2 mutant. Including the missed events by this method did not produce statistically significant changes in any parameters. The program displayed events for visual inspection and the onset point for curve fitting was adjusted individually in each event. The frequencies in individual neurons varied widely from 0 to $10 \mathrm{~Hz}$, and data from cells with a frequency $<0.1 \mathrm{~Hz}$ were discarded.

Events were fitted to Equation 1 in Results to determine the features of each mEPSC. Means are presented \pm SEM. For experiments with the same design (e.g., different mutants), one-way ANOVA with the Bonferroni post hoc test was used to evaluate the significance of changes within a group of mutants; the two-tailed $t$ test evaluated drug effects between two groups. For non-normal distributions with variance exceeding four 
A

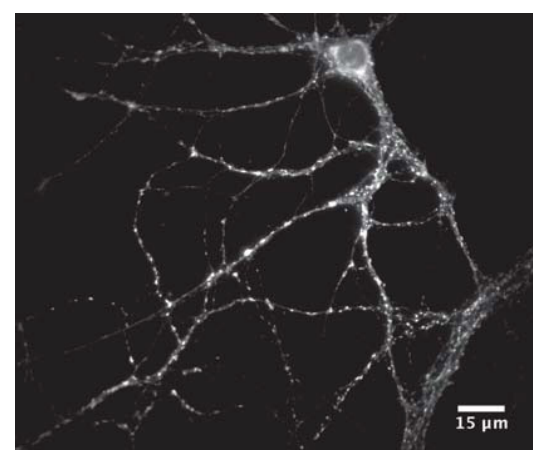

C

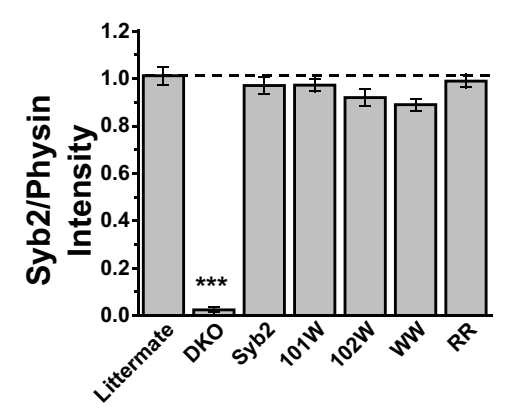

B

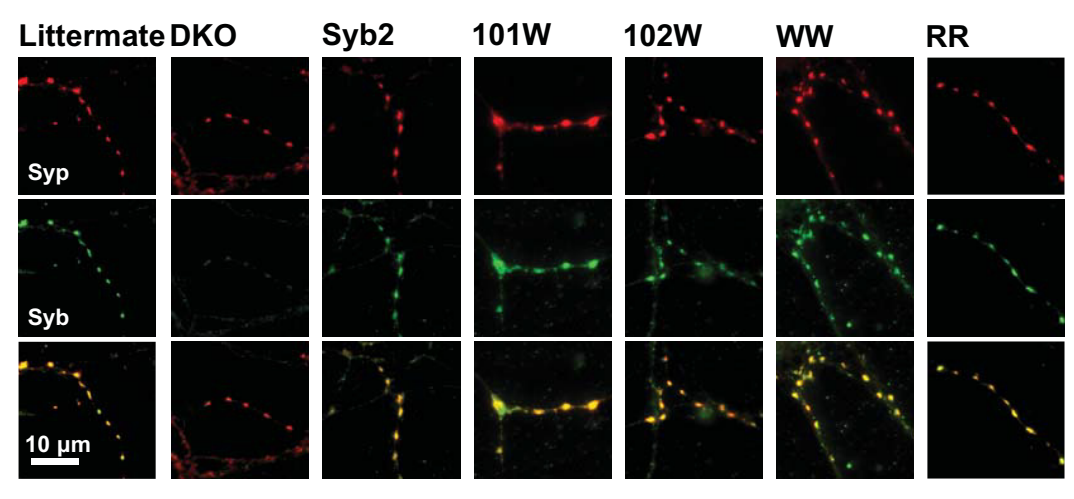

E

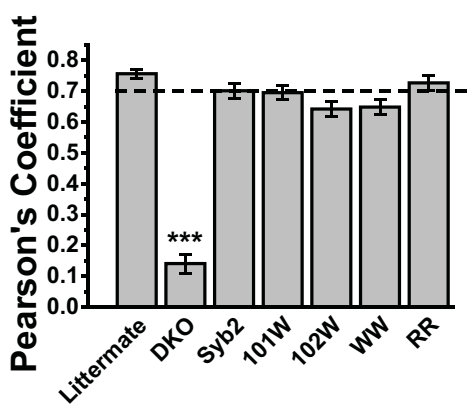

$\mathbf{F}$

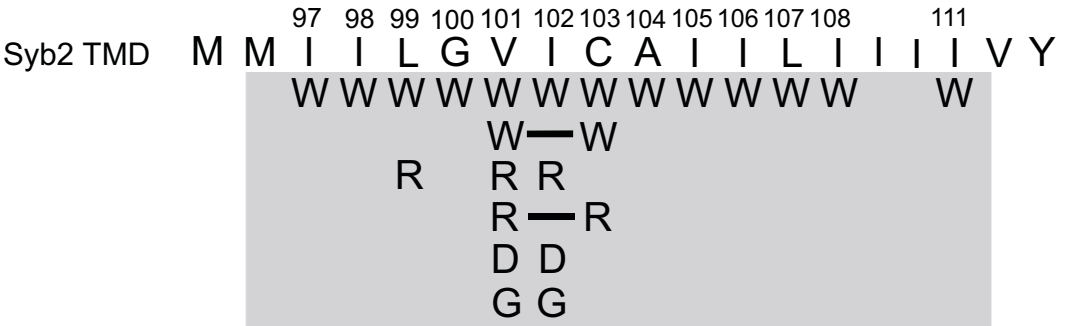

Figure 1. Expression of WT Syb2 and TMD mutants in dissociated Syb2/cellubrevin DKO hippocampal neurons. $A$, Syb2 immunofluorescence reveals synaptic boutons on the dendrites of a cultured neuron. B, Double immunofluorescence of dendritic segments with synaptic boutons show the endogenous synaptic vesicle marker synaptophysin (top, red), Syb2 (middle, green), and the two images merged (bottom), in littermate control neurons, untransfected neurons, and neurons expressing WT Syb2 or four selected TMD mutants, V101W, I102W, V101W/C103W (WW), and V101R/C103R (RR). C, The fluorescence intensity of puncta in Syb2 images such as those in $A$ and $B$ were compared. Intensities are indistinguishable between littermate neurons, DK0 cells expressing WT Syb2, and DKO cells expressing the selected Syb2 mutants. The puncta intensity in DKO $(N=19)$ was lower than littermate $\left(N=11\right.$; two-tailed Mann-Whitney test, $\left.U=209, p=7.6 \times 10^{-6}\right)$ and WT Syb2 $\left(N=19 ; U=361, p=1.5 \times 10^{-7}\right)$. All values were relative to synaptophysin (physin) intensity of the same image. $D$, The number of synapses per micrometer of dendrite, determined by synaptophysin immunofluorescence, was indistinguishable between all conditions examined using one-way ANOVA with the Bonferroni posthoctest. E, Colocalization between endogenous synaptophysin and overexpressed Syb2 was evaluated with Pearson's correlation coefficient, and was indistinguishable between Syb2 expressing neurons by one-way ANOVA with the Bonferroni post hoc test, but lower in untransfected DKO neurons. F, Schematic of Syb2 TMD displaying all the mutants (gray background) tested in this study. Solid lines indicate double amino acid substitutions. ${ }^{* * *} p<0.001$.

times the difference from control, the two-tailed Mann-Whitney test was used. The Kolmogorov-Smirnov test was used for distribution comparison. All statistical analysis was performed with Origin Pro software (OriginLab). For comparisons, asterisks indicate significance at the following levels: ${ }^{\star} p<0.05,{ }^{* *} p<0.01,{ }^{* *} p<0.001$, and specific $p$ values are presented in the text or legend.

mEPSCs generally show large amplitude variations (Finch et al., 1990; Bekkers, 1994), which can be attributed to differences in intravesicular concentration (Wu et al., 2007), vesicle size (Bekkers et al., 1990), dendritic filtering (Bekkers and Stevens, 1996), and receptor heterogeneity (Lomeli et al., 1994; Geiger et al., 1995). Some of these factors can influence the dynamic aspects of mEPSCs explored in the present study. Because of the considerable variation in properties of mEPSCs within and between neurons, we used a more conservative statistical analysis in which events are first averaged from each cell and comparisons made between the mean of cell means (Colliver et al., 2000). Error calculations were then based on cell number $(>20)$ rather than event number (range 1964-3776).

\section{Results}

\section{Syb2 expression and mEPSCs in DKO neurons}

Neurons from Syb2/Cellubrevin DKO mice have very low levels of exocytosis, and Syb2 overexpression fully rescues release to levels seen in cells from wild-type and littermate control mice (Borisovska et al., 2005; Guzman et al., 2010). This system thus provides a low background for testing Syb2 mutants by heterologous expression. To validate expression and targeting we used immunofluorescence to visualize proteins in neurons expressing WT-Syb2 and Syb2 TMD mutants (Fig. 1). These images revealed Syb2 in synapses (Fig. $1 A, B$, middle row, green) along with the synaptic vesicle marker synaptophysin (Fig. $1 B$, top row, red), 
A

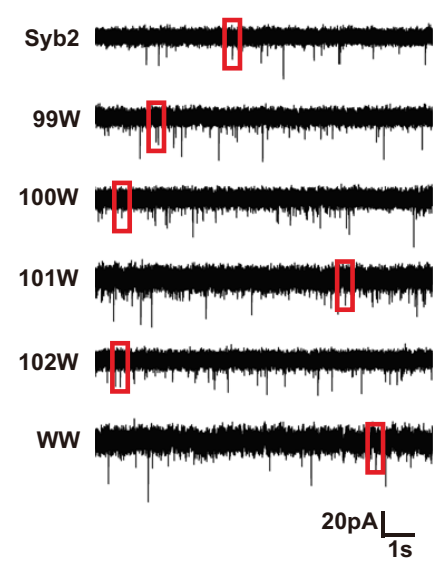

B

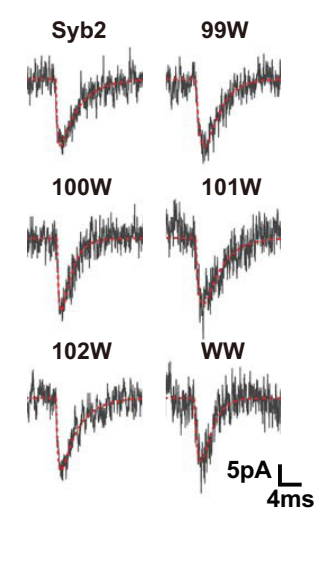

C

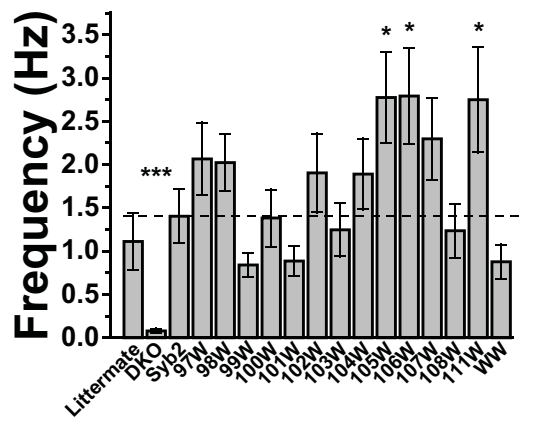

Figure 2. $\quad \boldsymbol{A}$, Whole-cell patch-clamp recordings reveal mEPSCs in cells transfected with WT-Syb2 or Syb2 mutants (events in red boxes displayed in $\boldsymbol{B}$ ). $\boldsymbol{B}$, Expanding the time axis for selected events from $\boldsymbol{A}$ illustrates the characteristic shapes of mEPSCs. Thin red curves show the fitted function (Eq. 1) used to obtain kinetic parameters. $\boldsymbol{C}$, mEPSC frequencies of littermate, DKO cells, and DKO cells transfected with WT-Syb2 and Syb2 mutants. Pairwise comparisons were conducted with the Mann-Whitney $U$ test. The frequency in untransfected DKO cells was markedly reduced. The frequencies in neurons expressing the Syb2 mutations 105W, 106W, and 111W were nearly twofold higher than in neurons expressing WT Syb2 and the differences were statistically significant (Mann-Whitney two-tailed, 105: $N=23, U=195, p=0.017,106: N=26, U=204, p=0.016,111: N=22, U=205, p=0.045) .{ }^{*} p<0.05,{ }^{* * *} p<0.001$.

with the two proteins in similar locations (Fig. $1 B$, bottom row, merged). The immunofluorescent puncta intensity of Syb2 relative to synaptophysin was indistinguishable between synapses expressing WT Syb2, four selected mutants, and littermate controls (Fig. 1C). Synaptophysin immunofluorescence showed that littermate controls and DKO neurons with or without various forms of expressed Syb2 had the same number of synapses per length of dendrite (Fig. 1D). Pearson correlation coefficients between Syb2 and synaptophysin immunofluorescence (background masked using the ImageJ autothreshold) indicated high colocalization (Fig. 1E), which was indistinguishable between DKO neurons expressing WT-Syb2 $(0.70 \pm 0.02, N=20$ images), DKO cells expressing Syb2 TMD mutants (ranging from $0.64 \pm 0.02$ to $0.73 \pm 0.02, N \geq 20$ images), and littermate control neurons ( $0.76 \pm 0.02, N=12$ images). Syb2 immunofluorescence could not be detected in untransfected DKO cells (Fig. $1 B, C)$. These results confirm that DKO cells provide a Syb2-free background, and further show that, like Syb2 linker mutants expressed in these cells (Guzman et al., 2010), Syb2 TMD mutants target synapses as effectively as the WT protein. We therefore tested a series of TMD mutants for effects on exocytosis, scanning residues $97-108$ and 111 with tryptophan substitutions to perform a systematic test of the impact of steric obstruction of the pore. We also tested selected locations with glycine in an effort to reverse tryptophan actions, arginine and aspartate to evaluate electrostatic interactions, and double arginine and tryptophan mutants to test for additivity (Fig. $1 F$ ).

Patch-clamp recordings revealed mEPSCs in DKO cells expressing Syb2 constructs. Ten-second-long traces illustrated the stochastic nature of spontaneous release (Fig. $2 A$ ), and individual events exhibited the characteristic shapes of mEPSCs (Fig. 2B). Untransfected DKO neurons had very low levels of spontaneous release, as judged by their mEPSC frequency of $<0.1 \mathrm{~Hz}$. Overexpressing WT-Syb2 rescued spontaneous release to $1.4 \pm 0.30$ $\mathrm{Hz}(N=28)$, a level similar to that seen in littermate control neurons of $1.1 \pm 0.33 \mathrm{~Hz}(N=29)$. Averaging frequency over cells within each group gave values ranging from 0.84 to $2.79 \mathrm{~Hz}$ (Fig. 2C). All Syb2 mutants had mEPSC frequencies well above untransfected DKO cells (e.g., DKO vs Syb2, Mann-Whitney two-tail, $\left.N=20, U=21.5, p=6.8 \times 10^{-8}\right)$, and most frequen- cies were within $50 \%$ of that seen in cells overexpressing WTSyb2 or littermate control cells; with three mutants toward the C-terminus (105W, 106W, and 111W), mEPSC frequencies significantly exceeded the frequency in WT-Syb2 by approximately twofold (Fig. 2C).

\section{TMD mutants and mEPSC properties}

We analyzed mEPSCs with a computer program that detected events of a characteristic shape with a sharp rise and slower decay. Events were then fitted to the following function (Clements and Bekkers, 1997)

$$
\mathrm{I}(\mathrm{t})=A \cdot\left(1-e^{-t / \tau_{1}}\right)\left(e^{-t / \tau_{2}}\right) .
$$

The curves yielded by these fits recapitulated the shapes of the recorded mEPSCs very well (Fig. $2 B$, fits illustrated by thin red curves), and the fitting parameters were used to calculate amplitude, area, and decay time. The maximum rising rate (max-riserate) was obtained from the derivative of the fitted curve and normalized to the amplitude of the event.

We examined 13 mutants with single tryptophan substitutions in the Syb2 TMD at positions 97 to 108 and 111 (Fig. $1 F$ ). mEPSCs recorded from DKO neurons overexpressing WT-Syb2 had a mean peak amplitude of $-15.8 \pm 1.2 \mathrm{pA}$. The distributions peaked well above our detection threshold of $\sim 5 \mathrm{pA}$ so that the average amplitude was not impacted by censoring of events too small to detect. The amplitude had a coefficient of variation (CV) of $0.38 \pm 0.02$, which was somewhat lower than previously reported values in cultured hippocampal neurons of $>0.5$ (Bekkers et al., 1990; Abdul-Ghani et al., 1996). This indicates that in our hands mEPSCs were relatively uniform. DKO cells overexpressing all the mutants tested here had mean peak amplitudes (Fig. $3 A$ ) and areas (Fig. 3B) similar to those in cells overexpressing WT-Syb2.

The max-rise-rate of an mEPSC represents the fastest rate of AMPA receptor channel opening. This rate in turn depends on the neurotransmitter concentration in the synaptic cleft, and the rise-rate is most rapid when the concentration peaks (Khanin et al., 1994; Clements, 1996; Stiles et al., 1996; Wahl et al., 1996). The max-rise-rate is thus the feature of an mEPSC with the closest 
A

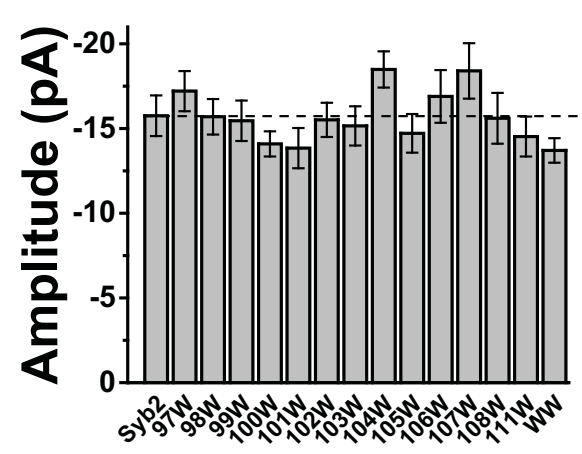

C

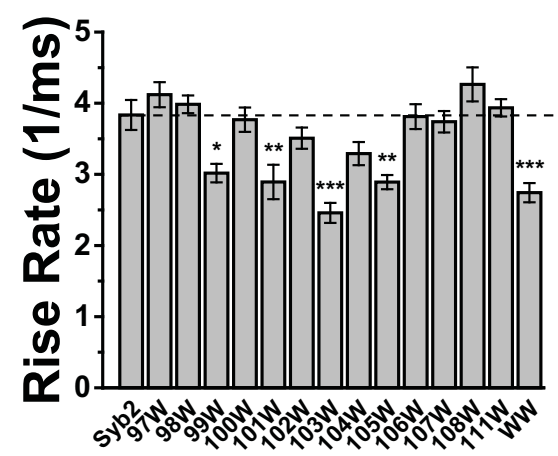

B

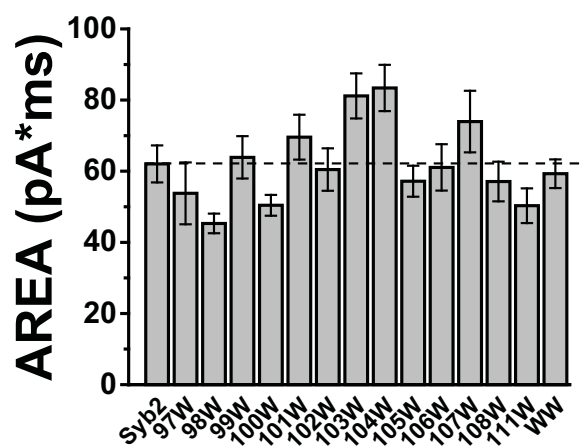

D

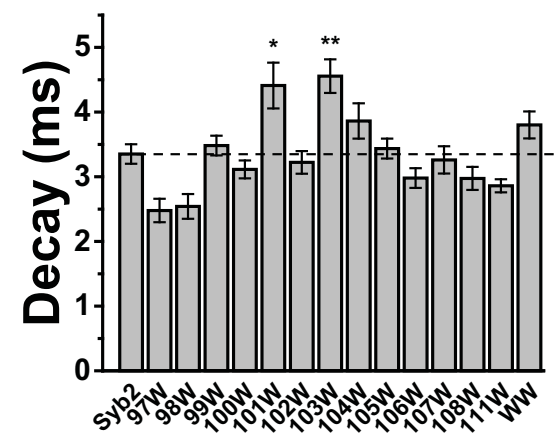

E

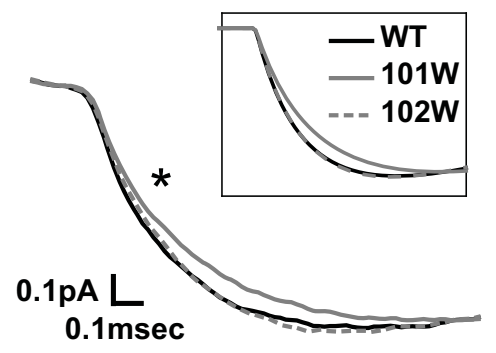

$\mathbf{F}$

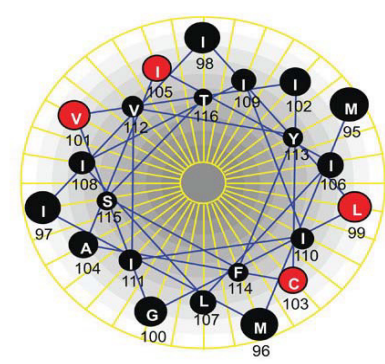

Figure 3. mEPSC characteristics in hippocampal neurons transfected with WT-Syb2 and Syb2 tryptophan TMD mutations. Single mutations were tested at residues $97-108$ and 111 . WW indicates a 101/103 double mutation (Fig. $1 F$ ). Bar graphs present the mean of cell means \pm SEM, with error based on cell number $(N \geq 22)$. $\boldsymbol{A}$, Amplitude and $(\boldsymbol{B})$ area were indistinguishable between all mutants and WT. C, Max-rise-rate; four single mutations and a double tryptophan mutation produced statistically significant reductions (Bonferroni test, $\mathrm{L} 99 \mathrm{~W}: \mathrm{N}=29, t=3.72, p=0.024$, V101W: $N=23, t=4.03, p=0.007,\left(103 \mathrm{~W}: N=26, t=6.09, p=3.0 \times 10^{-7}, \mathrm{I}\right.$ I05W: $\left.N=23, t=4.04, p=0.007 ; W W: N=26, t=4.83, p=2.1 \times 10^{-4}\right) . D$, Decay time; two single mutations produced statistically significant increases (Bonferroni test, V101W: $t=3.72, p=0.024, C 103 \mathrm{~W}: t=4.37, p=0.002$ ). $E$, Averaged recorded mEPSCs from neurons expressing WT Syb2, $101 \mathrm{~W}$, and 102W to illustrate the slower onset in neurons expressing 101W. The star indicates the trace for 101W differed significantly ( $N=51, p=0.013 ;$ Kolmogorov-Smirnov test). Inset, The averages of the fitted curves to illustrate that the fitting was faithful to the raw mEPSCs. $F$, A Helical wheel of the Syb2 TMD shows the residues where tryptophan reduced the max-rise-rate as red. The four sites fall along two different faces. ${ }^{*} p<0.05,{ }^{* *} p<0.01,{ }^{* * *} p<0.001$.

relationship to the flux through a fusion pore. Among the Syb2 TMD mutants tested here, neurons expressing L99W, V101W, $\mathrm{C} 103 \mathrm{~W}$, and I105W had significantly lower max-rise-rates (Fig. $3 C$ ), falling 20-35\% below the value with WT-Syb2 (3.84 \pm 0.21 $\left.\mathrm{ms}^{-1}\right)$. This suggests that tryptophan substitutions at these sites reduced transmitter flux through fusion pores. Two of the mutations that reduced the max-rise-rate also slowed the mEPSC decay, increasing the decay time constant by nearly $30 \%$ (Fig. 3D). This suggests that these mutations altered glutamate profiles in a manner that influenced kinetic processes involved in receptor deactivation/desensitization. A reduced fusion pore flux should extend the time glutamate occupies the synaptic cleft and increase the amount of desensitization. Simulations of transmitter diffusion and receptor activation presented below explore these possibilities. Our simulations reproduce previous studies (Scimemi and Beato, 2009) showing that for a given quantal content, reductions in the peak cleft concentration can be compensated by increases in the duration of the concentration transient to leave the amplitude and area relatively unchanged. Our measurements of amplitude and area confirm this prediction (Fig. $3 A, B$ ), and the changes in max-rise-rate (Fig. $3 C$ ) suggest that this quantity serves as a better indicator of changes in fusion pore flux. The slower rise of mEPSCs with the $101 \mathrm{~W}$ mutant compared with WT and $102 \mathrm{~W}$ can also be observed in average traces (Fig. 3E).
The four sites that reduced the max-rise-rate fell along two faces of an $\alpha$-helical projection of the Syb2 TMD (Fig. 3F), and these same four mutations also reduced flux of catecholamine through endocrine fusion pores (Chang et al., 2015). To see whether these effects were additive we made a double mutation with tryptophan substitutions at positions 101 and 103 (Fig. 1F). These two residues fall on two different faces of the helix (Fig. $3 F)$. The results for this mutant are included in Figure $3 A-D$ (labeled WW). The max-rise-rate was lower than in WT, but the reduction was indistinguishable from that produced by the single mutants. Thus, additive effects could not be detected. The decay time was in between that of WT-Syb2 and the two corresponding single mutants (101W and 103W), and not significantly different from either (Fig. 3D).

Cumulative probability distributions of amplitude (Fig. 4A) and area (Fig. $4 B$ ) were similar, as Illustrated for some selected mutations. By contrast, tryptophan substitutions at position 99, 101 , and 101/103 (99W, 101W, and WW) clearly shifted the maxrise-rates to smaller values over the entire range measured (Fig. $4 C$ ). The decay time distribution was also shifted with 101W (Fig. $4 D$ ). The broad shifts of the distributions indicate that mutations do not have a preferential action on a particular subpopulation of mEPSCs associated with part of the distribution, but rather that the mutations act on the entire population of events uniformly. 
A

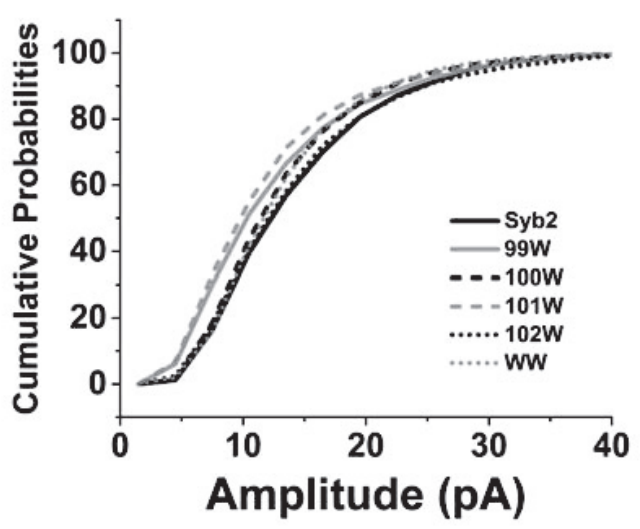

C

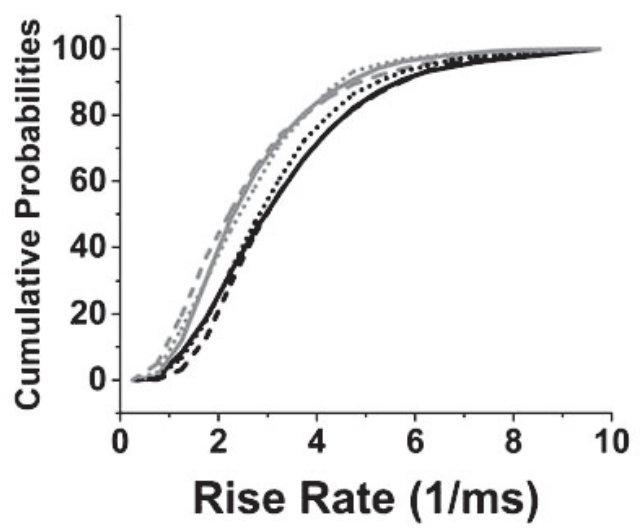

B

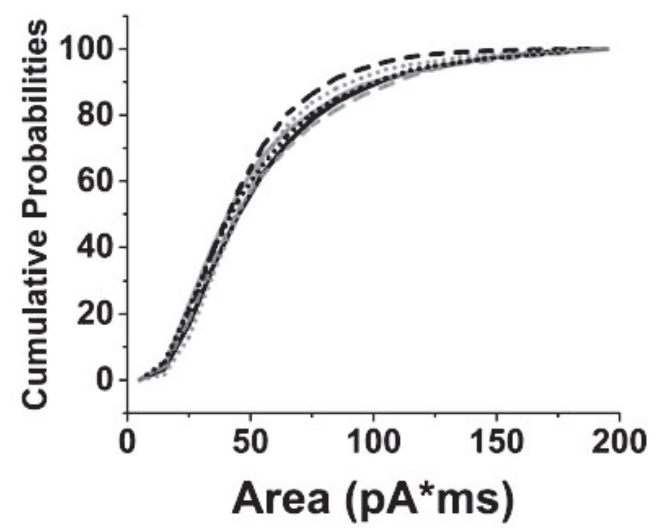

D

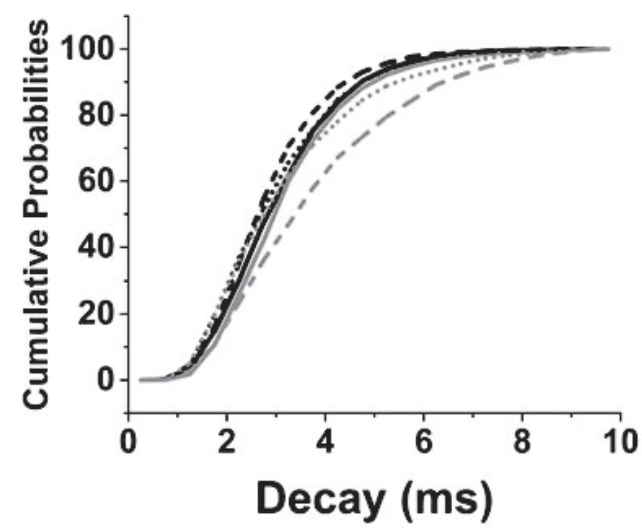

Figure 4. Cumulative probability plots of $(\boldsymbol{A})$ amplitude, $(\boldsymbol{B})$ area, $(\boldsymbol{C})$ max-rise-rate, and $(\boldsymbol{D})$ decay time. mEPSC parameters were pooled from 1964 to 3776 events recorded from hippocampal neurons transfected with WT-Syb2 and Syb2 with single tryptophan mutations at residues $99-102$ and the 101/103 WW double mutation, indicated by the legend of $\boldsymbol{A}$.

The mutations thus appear to be acting independently of the other sources of mEPSC variation.

We attempted to reverse the effect of tryptophan by expressing a mutant with glycine at position 101. We also substituted glycine at position 102 where tryptophan had no effect. Like tryptophan mutations, the glycine mutations (101G and 102G) did not alter mEPSC amplitudes (Fig. 5A) or areas (Fig. 5B). Glycine also failed to alter max-rise-rates (Fig. $5 C$ ) or decays (Fig. $5 D$ ), indicating that this small side chain did not produce changes opposite to those seen with tryptophan.

We then tested for electrostatic interactions by introducing arginine and aspartate. These charged residues should interact with the negative charge of glutamate and alter flux through the fusion pore, as seen previously with charged SNARE TMD residues in endocrine release (X. Han and Jackson, 2005; Chang et al., 2015). Charge had no impact on amplitude (Fig. 5A) or area (Fig. $5 B)$, but the max-rise-rate decreased in $101 \mathrm{R}$ and $101 \mathrm{R} / 103 \mathrm{R}$ (RR) by $\sim 20 \%$ compared with WT-Syb2 (Fig. 5C). The mutant 99R reduced the max-rise-rate by almost as much, but this change was not statistically significant. By contrast, negative charge substitutions had no effect on the max-rise-rate; substituting aspartate at positions 101 or 102 (101D and 102D) had no effect (Fig. 5C). None of the glycine, arginine, or aspartate mutations changed the decay times (Fig. 5D).
Among the non-tryptophan substitutions tested here, only arginine had an impact. Since the neurotransmitter glutamate carries a negative charge, it should be attracted to positively charged arginine. In endocrine fusion pores electrostatic attractions enhanced flux (X. Han and Jackson, 2005; Chang et al., 2015). However, our results indicated that electrostatic attractions reduced flux in synaptic pores. This may indicate a slowing of the exit of neurotransmitter from the fusion pore. It is notable that with all of the mutations tested, we only observed reductions in the max-rise-rate and never increases. Dendritic filtering, voltage-clamp dynamics, and receptor kinetics all could contribute to the difficulty of detecting more rapid rise rates. Simulations of diffusion and receptor activation presented below explore the potential role of receptor kinetics and a saturation of the rate of AMPA receptor channel opening at higher glutamate concentrations. These various issues are taken up in the Discussion.

\section{Receptor desensitization during mEPSCs}

Receptor desensitization has a significant impact on the time course of evoked EPSCs mediated by AMPA receptors (Trussell and Fischbach, 1989; Diamond and Jahr, 1995; Otis et al., 1996b). However, the impact of desensitization on quantal release is generally smaller, and this has been attributed to the shorter duration of the transient rise in transmitter concentration in the synaptic 
A

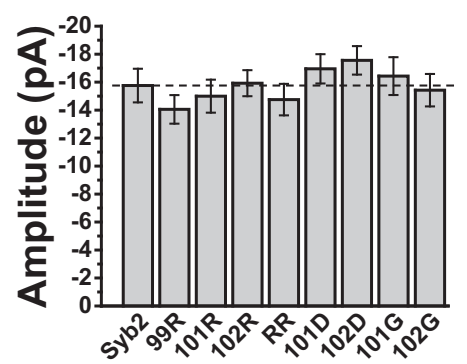

C

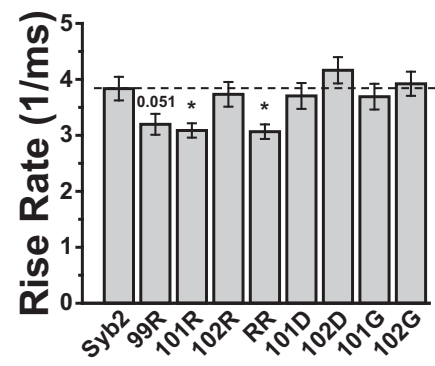

B

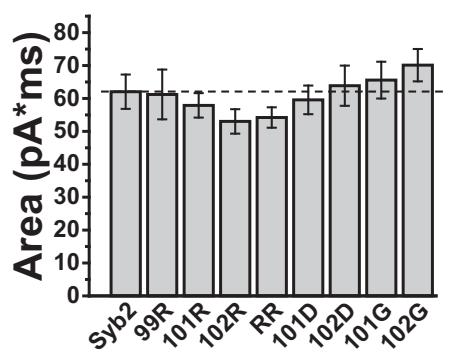

D

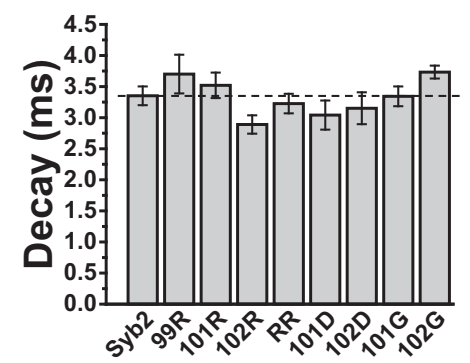

Figure 5. mEPSC amplitude $(\boldsymbol{A})$, area $(\boldsymbol{B})$, max-rise-rate $(\boldsymbol{C})$, and decay time $(\boldsymbol{D})$ from hippocampal neurons overexpressing Syb2 with the indicated glycine, arginine, and aspartate substitutions, and with a 101/103 double arginine substitution. Max-riserates were significantly reduced by two of the arginine mutations (Bonferroni test, 101R: $N=25, t=3.00, p=0.033, \mathrm{RR}: N=$ $25, t=3.08, p=0.025$ ). All groups had $\geq 20$ cells. ${ }^{*} p<0.05$.

cleft produced by the release of a single vesicle (Lawrence et al., 2003). Some of the mutants that reduced the max-rise-rate also prolonged mEPSC decay (Fig. 3), suggesting that reducing fusion pore flux will extend the time over which a vesicle loses content. The longer exposure of receptors to neurotransmitter could thus increase receptor desensitization. We attempted to test this idea with aniracetam, a drug known to prolong synaptic responses and reduce AMPA receptor desensitization and deactivation (Ito et al., 1990; Isaacson and Nicoll, 1991; Vyklicky et al., 1991), while sparing the release process (Vyklicky et al., 1991; Brenowitz and Trussell, 2001). Adding $2 \mathrm{~mm}$ aniracetam to the bathing solution significantly increased the amplitude $\left(t_{(48)}=3.58, p=8.0 \times\right.$ $\left.10^{-4}\right)$ and total area $\left(t_{(48)}=4.54, p=3.8 \times 10^{-5}\right)$ of mEPSCs in neurons expressing WT-Syb2 (Fig. $6 A, B$ ), as reported previously (Taylor et al., 1995; Brenowitz and Trussell, 2001; Lawrence et al., 2003). However, in contrast to these studies, aniracetam did not change the time constant for decay (Fig. 6C,D). Aniracetam had no effect on the max-rise-rate with WT Syb2 but produced a small significant reduction in the max-rise-rate with the WW mutant (Fig. 6C). The similar kinetics can also be seen with normalized average traces (Fig. $6 E$ ). In neurons transfected with the Syb2 WW mutant, aniracetam had a greater effect on mEPSCs. Not only were the amplitude $\left(t_{(48)}=4.47, p=4.8 \times 10^{-5}\right)$ and area $\left(t_{(48)}=6.63, p=2.6 \times 10^{-8}\right)$ increases greater, but the decay time was significantly prolonged (Fig. $6 A-D ; t_{(48)}=-4.11, p=$ $\left.1.5 \times 10^{-4}\right)$. The normalized averages show a clear increase in decay time (Fig. $6 E$ ), and this suggests that glutamate occupies the synaptic cleft for a longer time with this mutant, enabling receptor desensitization to influence the mEPSC time course. The modulation of the decay time by aniracetam when release is mediated by the WW-Syb2 mutant provides another line of evidence for a reduction of flux through synaptic fusion pores by a Syb2 TMD mutant. Simulations of receptor activation presented below assess these actions with the aid of kinetic models of AMPA receptor activation.

\section{Diffusion model of subsynaptic transmitter concentration}

Analysis of neurotransmitter diffusion in the synaptic cleft based on the diffusion equation (Khanin et al., 1994; Jackson, 2007; Chang et al., 2017) and Monte Carlo modeling (Clements, 1996; Stiles et al., 1996; Wahl et al., 1996; He et al., 2006) have explored how fusion pores can influence the shape of mEPSCs. To relate our results to fusion pores we used a diffusion model to simulate the time course of glutamate in the synaptic cleft. When transmitter diffuses through a fusion pore the number of transmitter molecules $N(t)$ as a function of time in a small cylindrical section of the cleft at the center of the release site can be obtained from the diffusion equation as a convolution integral.

$$
\mathrm{N}(\mathrm{t})=\frac{N_{0}}{4 \pi D \tau} \int^{t} \frac{e^{-s / \tau}}{t-s} d s
$$

This equation is from Chang et al. (2017, their Eq. 5) with the spatial coordinate $z$ set to zero to focus on the position directly under the release site where the concentration is highest. We take $D=0.33 \mu \mathrm{m}^{2} / \mathrm{ms}$ as the cleft diffusion constant (Nielsen et al., 2004), $N_{0}=1600$ as the initial number of glutamate molecules in a synaptic vesicle (Edwards, 1995), and the time constant of release, $\tau$, as $73 / \gamma \mu$ s, where $\gamma$ is the fusion pore conductance in nanoSiemens (Chang et al., 2017, their Eq. 3; Almers et al., 1991). This expression for $\tau$ took the measured ratio of catecholamine flux to conductance measured with patch-amperometry in chromaffin cells (Gong et al., 2007), and used this ratio for glutamate. Integrating Equation 2 numerically yields the time course of molecule number in the cleft for a given fusion pore conductance. The integration was halted at $s=t-0.2 \mu$ s to avoid the singularity at $t=s$ (the choice of $0.2 \mu$ s was based on the time to diffuse $20 \mathrm{~nm}$ across the synaptic cleft; Edwards, 1995). $N(t)$ was converted to concentration using the cleft width.

Figure $7 A$ displays the computed glutamate time course for values of $\gamma$ ranging from 100 to $700 \mathrm{pS}$. Peak concentration varied from 0.2 to $1.2 \mathrm{mM}$ (Fig. $7 B$ ). The times to peak became smaller with increasing pore conductance (Fig. $7 C$ ), but given that the concentration peaks in approximately one tenth the time that it takes for an mEPSC to peak, the speed of the concentration increase cannot be rate limiting. Thus, except when the pore conductance is very low the speed of the concentration rise is unlikely to play a significant role in the observed changes in mEPSC onset kinetics. The reduction in peak concentration is far more impactful than the change in time for concentration to peak. Figure 7, $A$ and $D$, illustrates that for $\gamma \geq 300 \mathrm{pS}$, glutamate in the cleft decays in $<1$ ms during synaptic transmission, in agreement with prior studies (Barbour et al., 1994; Otis et al., 1996a; Diamond, 2005; Scimemi and Beato, 2009; Kessler, 2013); clearance half-times in the range of 50-200 $\mu$ s are typical (Clements, 1996), but our results indicate that this time depends strongly on fusion pore conductance. The duration of the transient becomes longer as the pore conductance becomes smaller (Fig. $7 A, D$ ). These longer 
A

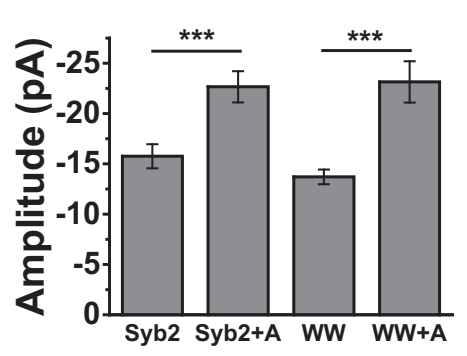

C

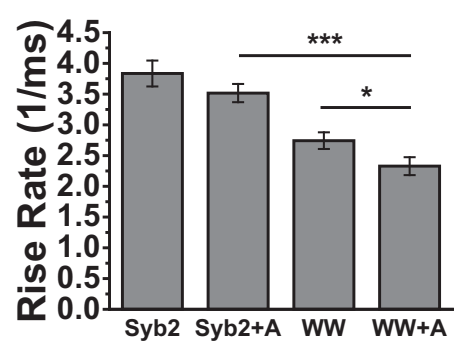

B

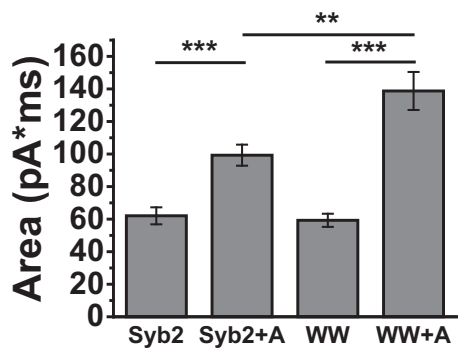

E

\section{Syb2}
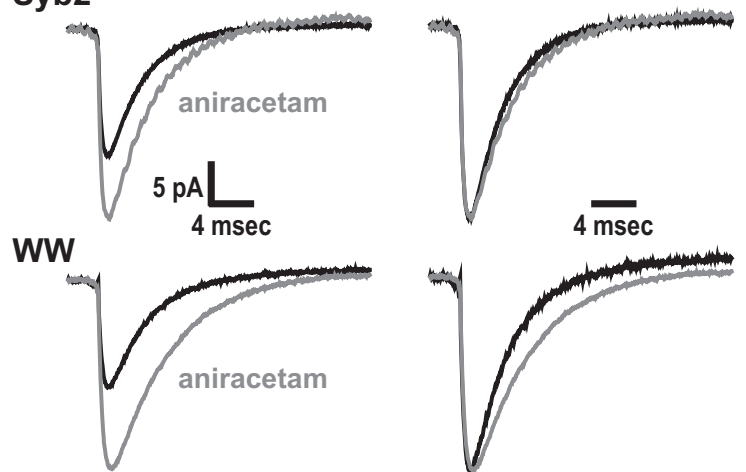

Figure 6. Reducing AMPA receptor desensitization with $2 \mathrm{~mm}$ aniracetam $(+A)$ altered $m E P S C s$ in neurons expressing WT Syb2 and the WW double-tryptophan mutant. Effects of aniracetam on (A) amplitude, $(\boldsymbol{B})$ area, $(\boldsymbol{C})$ max-rise-rate, and (D) decay time. Cell numbers: Syb2 $=28$, Syb2 $+A=22, W W=27$, and WW $+A=24$. For amplitudes the two-tailed $t$ test gave $p=8.0 \times 10^{-4}$ (WT) and $4.8 \times 10^{-5}$ (WW) for the significance of the aniracetam effect. For areas $p=3.8 \times 10^{-5}$ (WT) and $2.6 \times 10^{-8}$ (WW). Aniracetam had no significant effect on max-rise-rate for WT but the small reduction was significant with the WW mutation $(p=0.042)$. For decay time the effect was not significant for WT but was for WW $\left(p=1.5 \times 10^{-4}\right)$. $\boldsymbol{E}$, Averaged mEPSC traces for WT Syb2 (top) and WW mutant (bottom) in the absence (black) or presence (gray) of aniracetam. Averages on the right were normalized to their peaks to highlight the differences in decays. ${ }^{*} p<0.05$, ${ }^{* *} p<0.01,{ }^{* * *} p<0.001$.
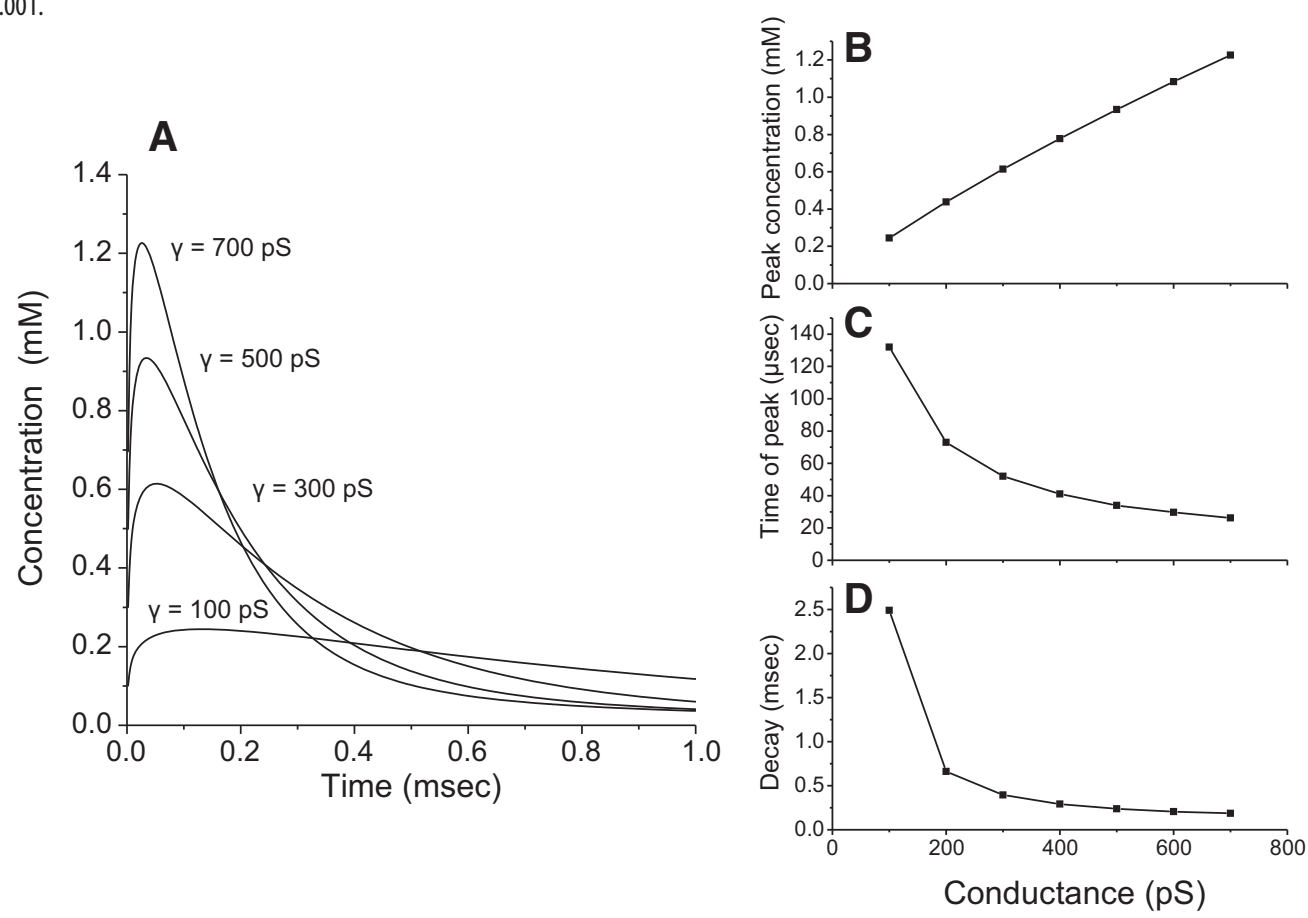

Figure 7. Simulations of cleft glutamate concentrations. A, Numerical integration of Equation 2 yielded the concentration versus time predicted by a diffusion model for the glutamate concentration in the synaptic cleft immediately below the site of fusion (Eq. 2). B, The peak concentration for simulations such as those in $\boldsymbol{A}$ plotted versus fusion pore conductance. C, Plot of time at peak. $\boldsymbol{D}$, Decay time during the falling phase of the concentration transient.

transients may be relevant to the slower decays seen with some mutants (Fig. 3D). To determine how the time course of cleft glutamate influences $\mathrm{mEPSC}$ shape we incorporated these results on diffusion into a model of receptor activation.

\section{Modeling receptor activation}

A number of studies have developed kinetic models of synaptic receptor activation based on rapid-solution-exchange experiments (Scimemi and Beato, 2009). For the present work we se- 
A

$$
\begin{aligned}
& C_{0} \underset{\mathrm{k}_{\text {off- }-1}}{\stackrel{2 \mathrm{k}_{\text {on }}}{\leftrightarrows}} C_{1} \underset{2 \mathrm{k}_{\text {off- }}}{\stackrel{\mathrm{k}_{\text {on }}}{\leftrightarrows}} C_{2} \underset{\alpha}{\stackrel{\beta}{\rightleftarrows}} \mathrm{O}_{2} \\
& k_{1} \downarrow\left|k_{-1} \quad k_{2}\right| \uparrow k_{-2} \\
& \text { B } \\
& D_{1} \underset{\text { off-3 }}{\stackrel{\mathrm{on}_{\text {off }}}{\leftrightarrows}} D_{2}
\end{aligned}
$$

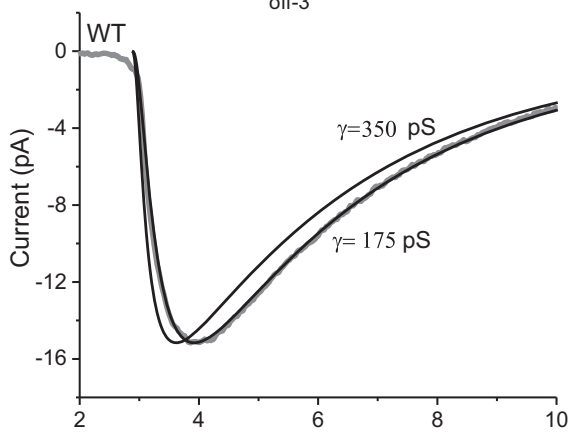

C

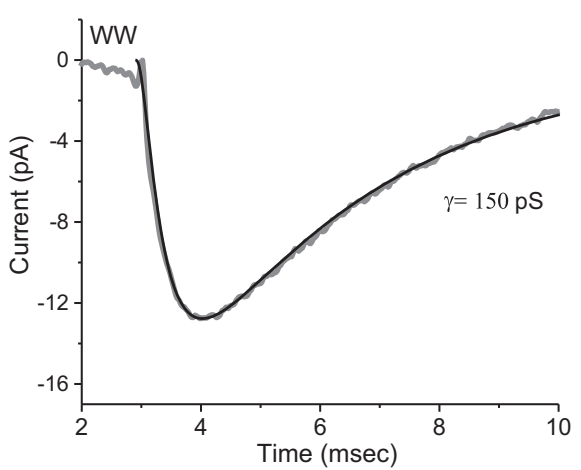

$\begin{array}{lll}\mathrm{k}_{\text {on }} & \mathrm{k}_{\text {off-3 }} & \mathrm{k}_{2} \\ 0.01 \mu \mathrm{M}^{-1} \mathrm{msec}^{-1} & 0.086 \mathrm{msec}^{-1} & 5 \mathrm{msec}^{-1} \\ \mathrm{k}_{\text {off-1 }} & \mathrm{k}_{1} & \mathrm{k}_{-2} \\ 0.3 \mathrm{msec}^{-1} & 0.9 \mathrm{msec}^{-1} & 0.008 \mathrm{msec}^{-1} \\ \mathrm{k}_{\text {off-2 }} & \mathrm{k}_{-1} & \beta \\ 30 \mathrm{msec}^{-1} & 0.5 \mathrm{msec}^{-1} & 20 \mathrm{msec}^{-1}\end{array}$

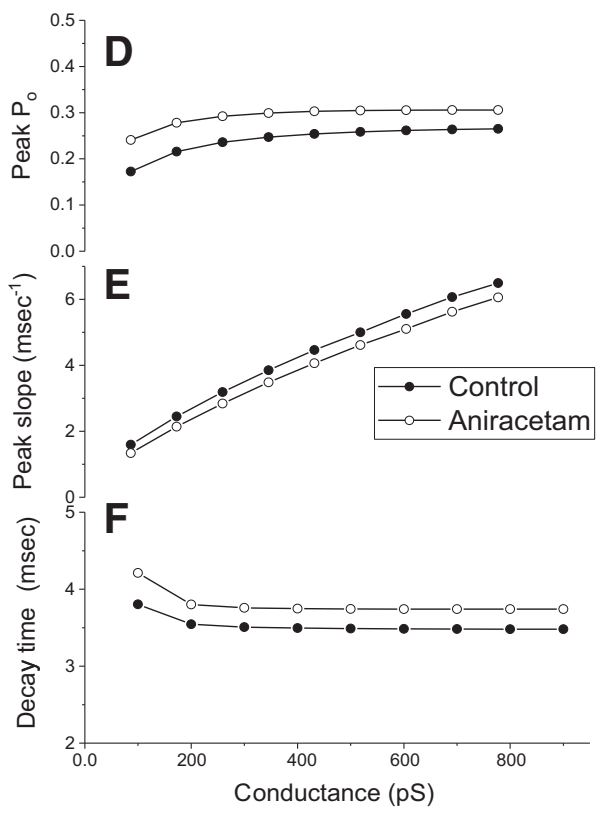

Figure 8. Simulations of receptor activation. $\boldsymbol{A}$, The model of Lawrence et al. (2003) was used to simulate receptor activation by glutamate emerging from a fusion pore with a given conductance using a glutamate concentration profile determined from Equation 2 as in Figure 7. The integration was performed with Mathcad 15; various differential equation solvers within this program (Rung-Kutta, Adams, Bulstoer) were tested and found to produce identical results. The following values were taken for the rate constants from Lawrence et al. (2003). $k_{\text {on }}=0.01 \mu \mathrm{m}{ }^{-1} \mathrm{~ms}^{-1}$, $k_{\text {off- } 1}=0.3 \mathrm{~ms}^{-1}, k_{\text {off-2 }}=30 \mathrm{~ms}^{-1}, k_{\text {off-3 }}=0.086 \mathrm{~ms}^{-1}, k_{1}=0.9 \mathrm{~ms}^{-1}, k_{-1}=0.5 \mathrm{~ms}^{-1}, k_{2}=5 \mathrm{~ms}^{-1}, k_{-2}=0.008 \mathrm{~ms}^{-1}$, and $\beta=20 \mathrm{~ms}^{-1}$. The value of $\alpha$ used by Lawrence et al. (2003) of $2.875 \mathrm{~ms}^{-1}$ is not consistent with the slow mEPSC decays observed here in mouse neurons and this value was reduced to $0.43 \mathrm{~ms}^{-1}$ to increase the decay time from 1.6 to $3.5 \mathrm{~ms}$. $\boldsymbol{B}$, The average of the mEPSCs recorded from neurons expressing WT Syb2 is displayed (gray) along with model simulations with fusion pore conductances of 175 and $350 \mathrm{pS}$. C, The average mEPSC from neurons expressing the WW mutant is displayed with a simulation identical to those in $\boldsymbol{B}$, but with $\gamma$ reduced to $150 \mathrm{pS}$ to fit the data. $\boldsymbol{D}$, Peak open probability of the AMPA receptor channel from simulations versus fusion pore conductance. For aniracetam we reduced $k_{1}$ to $1.2 \mathrm{~ms}^{-1}$ and $k_{2}$ to $0.8 \mathrm{~ms}^{-1}$ (based on Lawrence et al., 2003) but kept $\alpha$ at 0.43 ms ${ }^{-1}$; control points were represented by filled circles and aniracetam points by open circles. $\boldsymbol{E}$, Peak rising slope versus conductance. $\boldsymbol{F}$, Decay time versus pore conductance.

lected two models of AMPA receptors, one in cultured rat hippocampal neurons (Diamond and Jahr, 1997), and one in the chick cochlear nucleus (Lawrence et al., 2003). The system of rate equations from each of these models was solved (Fig. 8, see legend) with the glutamate concentration varying in time according to Equation 2. We normalized the simulation to the average WT mEPSC and varied the channel closing rate, $\alpha$ (Fig. $8 A$ ), to obtain decays similar to our experiments. This change in $\alpha$ reflected differences between the mEPSC decays of our experiments versus the experiments used to generate the models (Diamond and Jahr, 1997; Lawrence et al., 2003). Adjusting only $\alpha$ and the fusion pore conductance, $\gamma$, enabled us to replicate the average mEPSC essentially perfectly with both models while keeping all the other kinetic parameters at their published values. Because the chick receptor study included an evaluation of aniracetam, we focused on that model and presented those results here (Fig. 8). However, the rat receptor model (Diamond and Jahr, 1997) worked equally well for mEPSCs in the control solution.

Figure $8 \mathrm{~A}$ displays the kinetic model for the chick receptor, with parameter values to the right. With a fusion pore conductance of $0.175 \mathrm{nS}$ and $\alpha=0.43 \mathrm{~ms}^{-1}$, the model matched the average WT Syb2 mEPSC very well (Fig. $8 B$ ). The simulated mEPSC was sensitive to the choice of conductance; with $\gamma=350$ $\mathrm{pS}$ the rise was faster and the peak came at an earlier time (Fig. $8 B$ ). To simulate the mEPSC in neurons expressing the WW mutant the conductance was reduced from 175 to $150 \mathrm{nS}$, and all the other parameters were kept the same. This one adjustment yielded a trace that replicated the WW mEPSC (Fig. 8C). These results indicate that the mEPSC time course is well described by glutamate diffusion through a fusion pore followed by the activation of AMPA receptors. The simulated MEPSC is quite sensitive to $\gamma$ and allows us to estimate its value. However, these mEPSC simulations do not include dendritic filtering of the synaptic current, and use the glutamate concentration immediately below the release site where it is highest. Because these factors slow the onset of the mEPSC, the conductance that produces the best fit could be lower than the actual value. Our estimate of conductance is also sensitive to $N_{\mathrm{o}}$, the number of glutamate molecules in a vesicle. Increasing $N_{\mathrm{o}}$ from 1600 to 3200 increased the peak slope of the mEPSC onset by $\sim 30 \%$, but left the decay virtually unchanged. Thus, if $N_{\mathrm{o}}$ is higher than the value we used, our estimate of the pore conductance would be lower. 
We simulated mEPSCs for a range of conductance values and determined the peak open probability, $P_{\mathrm{o}}$ (Fig. $8 D$ ), max-riserate (Fig. $8 E$ ), and decay time (Fig. $8 F$ ). $P_{\mathrm{o}}$ varies a little at the low end of the plot even though the peak concentration rises quite steeply (Fig. $7 B$ ), confirming previous simulations suggesting that mEPSC amplitude is not very sensitive to peak concentration (Scimemi and Beato, 2009). The steep increase in peak slope in Figure $8 E$ demonstrates that this quantity is sensitive to fusion pore conductance, and supports our interpretation of the changes in max-rise-rate produced by some mutants. The decay time is relatively insensitive to pore conductance (Fig. $8 F$ ). This insensitivity of decay time suggests that detecting such changes experimentally will be more difficult, and this may explain why some mutants that altered the max-rise-rate failed to alter the decay time (Figs. 3, 5). Indeed, the observed changes in decay time are larger than expected from the model. The $\sim 10 \%$ increase at the low end of the plot is less than the largest increases of $\sim 30 \%$ seen with some mutants (Fig. $3 D$ ). Because the Syb2 TMD is unlikely to alter receptor properties, this discrepancy suggests that the model does not fully capture receptor behavior underlying the decay.

We also modeled the effect of aniracetam by reducing the rates of transitions to desensitized states ( $k_{1}$ and $k_{2}$; Fig. $8 \mathrm{~A}$ and legend), as specified by (Lawrence et al., 2003). Because aniracetam had much weaker effects on mEPSC decay times in our experiments we retained our value for the channel closing rate, $\alpha=0.43$ $\mathrm{ms}^{-1}$. The results are shown with open circles in Figure $8 D-F$. Replacing the values of $k_{1}$ and $k_{2}$ with values used by Lawrence et al. for aniracetam increased $P_{\mathrm{o}}$ (Fig. $8 D$ ), and for lower conductances the increase was close to the increase in mEPSC amplitude that we observed experimentally (Fig. 6A). The greater effect on $\mathrm{P}_{\mathrm{o}}$ for small conductances is consistent with our observation of a greater effect of aniracetam on mEPSCs in neurons expressing the mutant. A slightly greater effect of conductance on decay time is evident at the low conductance end of the plot (Fig. $8 F$ ), again corresponding with the observation that aniracetam increased the decay time with the WW mutant but not with WT Syb2. Glutamate receptors can desensitize on millisecond timescales even with glutamate concentrations well below those that strongly activate receptors (Raman and Trussell, 1995; Häusser and Roth, 1997; Heckmann and Dudel, 1997). This can be explained by desensitization of receptors from states of partial binding site occupancy. The temporal dispersion of concentration over longer times (Fig. $7 A, D$ ) should favor desensitization over activation, allowing fusion pore conductance to influence mEPSC decays. In summary, the model produced a quantitative reconstruction of mEPSCs and captured qualitative changes in their decay. It is likely that a modification of the kinetic model to incorporate more rapid desensitization from the $\mathrm{C}_{1}$ state (Fig. $8 A$ ), and tonic desensitization by ambient glutamate, will provide a more quantitative description of the changes in mEPSC decays.

\section{Discussion}

These experiments showed that Syb2 TMD residues influence the kinetics of synaptic release. TMD mutations altered the max-riserate of mEPSCs in a manner consistent with interactions with glutamate as it passes through the fusion pore. Our simulations showed that changes in pore conductance can account for these results. Only a few prior studies have shown that presynaptic molecular manipulations can alter the kinetics of synaptic release (Pawlu et al., 2004; Guzman et al., 2010; Bao et al., 2018). By focusing on the steep mEPSC rise, and conducting a systematic study of the Syb2 TMD, we were able to observe changes in re- lease kinetics that provide insight into the properties of synaptic fusion pores. These results support theoretical predictions that fusion pores can influence mEPSCs, and indicate that mEPSCs provide a useful surrogate for fusion pore flux.

\section{The properties of synaptic fusion pores}

Tryptophan and arginine substitutions in the Syb2 TMD slowed mEPSC onset, but enlarging the pore by replacing with glycine had no effect. Likewise, negatively charged aspartate and positively charged arginine should have opposite effects, but aspartate had no effect. In evaluating these results, one must bear in mind that mEPSC shape also reflects receptor activation. An initial binding step is followed by channel gating, and gating will be rate limiting at high glutamate concentration. Our simulations showed a modest decline in steepness in the plot of rise-rate versus conductance (Fig. $8 E$ ). Thus, reductions in pore size will have greater effects than increases. However, factors such as dendritic filtering and our use of the central cleft concentration in our diffusion model make it difficult to know where we are on this curve. If saturation explains our failure to see increases in max-rise-rate, then that would suggest WT fusion pores produce a glutamate flux that is near optimal for rapid receptor activation. Given this limitation in using mEPSCs to probe fusion pores, the present results can be viewed as broadly consistent with the more robust measurement of fusion pore flux from amperometry studies of the Syb2 TMD in endocrine cells (Chang et al., 2015).

However, the present results differed in an important way from the prior endocrine work. In endocrine cells arginine reduced flux and aspartate increased it (X. Han and Jackson, 2005; Chang et al., 2015). This suggests a simple electrostatic repulsion between positively charged arginine and catecholamine. In synapses with negatively charged glutamate, arginine should do the opposite and increase flux through synaptic pores. The reduction of flux by arginine suggests that an attraction to glutamate can increase its residence time in the fusion pore and reduce the exit rate. This difference may reflect different sizes or structures of synaptic and endocrine fusion pores (Klyachko and Jackson, 2002; He et al., 2006). Ionic screening and image forces are sensitive to pore size and these interactions are likely to lead to a nonlinear dependence of pore conductance on the charge lining the pore. Differences in the properties of glutamate and catecholamine aside from charge could also have an impact. Finally, it is possible that the similar flux-reducing effect of arginine in both synaptic and endocrine fusion pores reflects the large volume of its side chain (second largest of the $20 \mathrm{aa}$ ), so that steric interactions dominate.

Although the conductances of fusion pores formed by small synaptic vesicle-like vesicles and large dense-core vesicles differ by an order of magnitude (Klyachko and Jackson, 2002), the parallels seen with tryptophan mutagenesis indicate that these different sized pores share some significant architectural features. Experiments with reconstituted membranes in vitro indicate that SNARE TMD mutations reduce fusion pore flux, and side chains become accessible to water (Bao et al., 2016). Although the patterns of residue involvement in fusion pores were the same between endocrine cells and synapses, this pattern only partially overlapped with the patterns in reconstituted systems, where two different methods, flux and chemical labeling, generated patterns that only partially overlapped with one another (Bao et al., 2016; Chang et al., 2017). This may indicate structural differences between the fusion pores formed during SNARE-mediated fusion in vitro and in vivo, as well as differences in the methods used to identify pore liners. 
There are a number of results in the literature that are difficult to reconcile with a proteinaceous fusion pore. The minimal number of SNAREs needed for fusion provides too few TMDs to form a channel (Mohrmann et al., 2010; van den Bogaart et al., 2010; Sinha et al., 2011; Bao et al., 2016), and membrane label flux has been observed in advance of aqueous label flux (Zhao et al., 2016). These differences may indicate that fusion pores contain both protein and lipid, with a composition that can vary with the number of SNAREs (Chang et al., 2017). When there are too few SNAREs to form an aqueous pore, fusion may be able to bypass the proteinaceous channel. Incorporating more SNARE copies enables the TMDs to form an aqueous pore. The number would have to be quite large to create a pore of $175 \mathrm{pS}$ (X. Han et al., 2004; Zhang et al., 2010). Formation of a proteinaceous fusion pore may be a cooperative process requiring a greater number of SNAREs.

Fusion pores formed during kiss-and-run exocytosis of small vesicles have small conductances $<100 \mathrm{pS}$ (Klyachko and Jackson, 2002; He et al., 2006). With full fusion, capacitance experiments could only determine a lower bound of $256 \mathrm{pS}$ (He et al., 2006). Based on our modeling we estimated a conductance of $\sim 175 \mathrm{pS}$ for WT fusion pores. TMD mutations appeared to reduce the conductance by $\sim 17 \%$, but these mutations had larger effects on pore conductance in endocrine cells (Chang et al., 2015).

\section{Syb2 TMD associations}

The four amino acids in the Syb2 TMD implicated as pore liners fall on two nearly opposite helical faces located toward the cytoplasmic end of the TMD (Fig. 3). This suggests that Syb2 adopts two distinct conformations within the fusion pore. Purified complexes of Syb2 and synaptophysin form a ring structure containing six copies of synaptophysin and 12 copies of Syb2 surrounding a central pore-like cavity (Adams et al., 2015). The Syb2 copies appear as pairs in this structure, with the two TMDs in different orientations, each with different inward facing residues (Chang et al., 2017, their Fig. 2). The residues identified as pore liners both previously (Chang et al., 2015), and in the present work (Fig. $3 F$ ), face into the central pore in this structure, demonstrating a remarkable convergence of results from two very different lines of experimentation.

Syb2 TMDs dimerize in vitro (Laage and Langosch, 1997), and various residues have been proposed to form the contact surface (Laage et al., 2000; Fleming and Engelman, 2001; Roy et al., 2004). Simulations suggested Syb2 can TMDs dimerize, with L99, C103, L107, and I111 at the helix-helix interface; V101 and I105 support the formation of larger oligomers (J. Han et al., 2015, 2016). Although our current model of the fusion pore supports Syb2 TMD dimerization, its function in $\mathrm{Ca}^{2+}$-triggered exocytosis remains unclear. Indeed, a physiological role for dimerization has been difficult to demonstrate (Fdez et al., 2010). Substituting tryptophan at contact sites should inhibit dimerization, but none of the mutations tested here impaired spontaneous release. Three of the mutations actually enhanced release (Fig. $2 E$ ), but the large cell-to-cell variation in mEPSC frequency makes these changes difficult to interpret. The finding that tryptophan mutants did not seriously disrupt function contrasts with findings from tryptophan-scanning in a number of other membrane proteins where disruptive effects were interpreted as evidence for tightly packed TMDs (Monks et al., 1999; De Feo et al., 2010; Depriest et al., 2011; Lloris-Garcerá et al., 2013). The tolerance of SNARE TMDs to tryptophan incorporation both in the present study and previously (X. Han et al., 2004; Chang and Jackson, 2015) could reflect looser packing, or more exposure of the TMDs to lipid or water. Looser packing would create an environment in which TMDs can bend more easily, which may be important for the catalysis of membrane fusion (Jackson, 2010; Dhara et al., 2016).

\section{Conclusions}

The time course of mEPSCs is sensitive to fusion pore perturbations and offers an indirect approach to testing models of pore structure. Here we demonstrated that the Syb2 TMD influences mEPSCs in a manner consistent with an effect on transmitter flux through synaptic fusion pores. This suggests that Syb2 TMDs are exposed to the lumen of the synaptic fusion pore, and supports a protein contribution to pore formation. These results thus extend a model for fusion pores that had been used to interpret conceptually similar experiments in endocrine cells (X. Han et al., 2004; X. Han and Jackson, 2005; Chang et al., 2015) and reconstituted lipid membranes (Bao et al., 2016). By comparing findings on synaptic fusion pores with previous findings with the same TMD mutations in chromaffin cells, our results suggest that synaptic vesicles and large dense-core vesicles, despite their many differences in properties and function, may undergo $\mathrm{Ca}^{2+}$ triggered exocytosis through an intermediate with significant similarities in architecture and molecular composition.

\section{References}

Abdul-Ghani MA, Valiante TA, Pennefather PS (1996) Sr2+ and quantal events at excitatory synapses between mouse hippocampal neurons in culture. J Physiol 495:113-125. CrossRef Medline

Adams DJ, Arthur CP, Stowell MH (2015) Architecture of the synaptophysin/synaptobrevin complex: structural evidence for an entropic clustering function at the synapse. Sci Rep 5:13659. CrossRef Medline

Almers W, Breckenridge LJ, Iwata A, Lee AK, Spruce AE, Tse FW (1991) Millisecond studies of single membrane fusion events. Ann N Y Acad Sci 635:318-327. CrossRef Medline

Bao H, Goldschen-Ohm M, Jeggle P, Chanda B, Edwardson JM, Chapman ER (2016) Exocytotic fusion pores are composed of both lipids and proteins. Nat Struct Mol Biol 23:67-73. CrossRef Medline

Bao H, Das D, Courtney NA, Jiang Y, Briguglio JS, Lou X, Roston D, Cui Q, Chanda B, Chapman ER (2018) Dynamics and number of trans-SNARE complexes determine nascent fusion pore properties. Nature 554:260263. CrossRef Medline

Barbour B, Keller BU, Llano I, Marty A (1994) Prolonged presence of glutamate during excitatory synaptic transmission to cerebellar purkinje cells. Neuron 12:1331-1343. CrossRef Medline

Bekkers JM (1994) Quantal analysis of synaptic transmission in the central nervous system. Curr Opin Neurobiol 4:360-365. CrossRef Medline

Bekkers JM, Stevens CF (1996) Cable properties of cultured hippocampal neurons determined from sucrose-evoked miniature EPSCs. J Neurophysiol 75:1250-1255. CrossRef Medline

Bekkers JM, Richerson GB, Stevens CF (1990) Origin of variability in quantal size in cultured hippocampal neurons and hippocampal slices. Proc Natl Acad Sci U S A 87:5359-5362. CrossRef Medline

Borisovska M, Zhao Y, Tsytsyura Y, Glyvuk N, Takamori S, Matti U, Rettig J, Südhof T, Bruns D (2005) v-SNAREs control exocytosis of vesicles from priming to fusion. EMBO J 24:2114-2126. CrossRef Medline

Brenowitz S, Trussell LO (2001) Minimizing synaptic depression by control of release probability. J Neurosci 21:1857-1867. CrossRef Medline

Bruns D, Jahn R (1995) Real-time measurement of transmitter release from single synaptic vesicles. Nature 377:62-65. CrossRef Medline

Chang CW, Chiang CW, Gaffaney JD, Chapman ER, Jackson MB (2016) Lipid-anchored synaptobrevin provides little or no support for exocytosis or liposome fusion. J Biol Chem 291:2848-2857. CrossRef Medline

Chang CW, Chiang CW, Jackson MB (2017) Fusion pores and their control of neurotransmitter and hormone release. J Gen Physiol 149:301-322. CrossRef Medline

Chang CW, Jackson MB (2015) Synaptobrevin transmembrane domain influences exocytosis by perturbing vesicle membrane curvature. Biophys J 109:76-84. CrossRef Medline

Chang CW, Hui E, Bai J, Bruns D, Chapman ER, Jackson MB (2015) A 
structural role for the synaptobrevin 2 transmembrane domain in densecore vesicle fusion pores. J Neurosci 35:5772-5780. CrossRef Medline

Clements JD (1996) Transmitter timecourse in the synaptic cleft: its role in central synaptic function. Trends Neurosci 19:163-171. CrossRef Medline

Clements JD, Bekkers JM (1997) Detection of spontaneous synaptic events with an optimally scaled template. Biophys J 73:220-229. CrossRef Medline

Colliver TL, Hess EJ, Pothos EN, Sulzer D, Ewing AG (2000) Quantitative and statistical analysis of the shape of amperometric spikes recorded from two populations of cells. J Neurochem 74:1086-1097. CrossRef Medline

De Feo CJ, Mootien S, Unger VM (2010) Tryptophan scanning analysis of the membrane domain of CTR-copper transporters. J Membr Biol 234: 113-123. CrossRef Medline

Depriest A, Phelan P, Martha Skerrett I (2011) Tryptophan scanning mutagenesis of the first transmembrane domain of the innexin shakingB(lethal). Biophys J 101:2408-2416. CrossRef Medline

Dhara M, Yarzagaray A, Makke M, Schindeldecker B, Schwarz Y, Shaaban A, Sharma S, Böckmann RA, Lindau M, Mohrmann R, Bruns D (2016) $\mathrm{v}$-SNARE transmembrane domains function as catalysts for vesicle fusion. eLife 5:e17571. CrossRef Medline

Diamond JS (2005) Deriving the glutamate clearance time course from transporter currents in CA1 hippocampal astrocytes: transmitter uptake gets faster during development. J Neurosci 25:2906-2916. CrossRef Medline

Diamond JS, Jahr CE (1995) Asynchronous release of synaptic vesicles determines the time course of the AMPA receptor-mediated EPSC. Neuron 15:1097-1107. CrossRef Medline

Diamond JS, Jahr CE (1997) Transporters buffer synaptically released glutamate on a submillisecond time scale. J Neurosci 17:4672-4687. CrossRef Medline

Domanska MK, Kiessling V, Stein A, Fasshauer D, Tamm LK (2009) Single vesicle millisecond fusion kinetics reveals number of SNARE complexes optimal for fast SNARE-mediated membrane fusion. J Biol Chem 284: 32158-32166. CrossRef Medline

Edwards FA (1995) Anatomy and electrophysiology of fast central synapses lead to a structural model for long-term potentiation. Physiol Rev 75: 759-787. CrossRef Medline

Fdez E, Martínez-Salvador M, Beard M, Woodman P, Hilfiker S (2010) Transmembrane-domain determinants for SNARE-mediated membrane fusion. J Cell Sci 123:2473-2480. CrossRef Medline

Finch DM, Fisher RS, Jackson MB (1990) Miniature excitatory synaptic currents in cultured hippocampal neurons. Brain Res 518:257-268. CrossRef Medline

Fleming KG, Engelman DM (2001) Computation and mutagenesis suggest a right-handed structure for the synaptobrevin transmembrane dimer. Proteins 45:313-317. CrossRef Medline

Gao Y, Zorman S, Gundersen G, Xi Z, Ma L, Sirinakis G, Rothman JE, Zhang Y (2012) Single reconstituted neuronal SNARE complexes zipper in three distinct stages. Science 337:1340-1343. CrossRef Medline

Geiger JR, Melcher T, Koh DS, Sakmann B, Seeburg PH, Jonas P, Monyer H (1995) Relative abundance of subunit mRNAs determines gating and $\mathrm{Ca} 2+$ permeability of AMPA receptors in principal neurons and interneurons in rat CNS. Neuron 15:193-204. CrossRef Medline

Gong LW, de Toledo GA, Lindau M (2007) Exocytotic catecholamine release is not associated with cation flux through channels in the vesicle membrane but $\mathrm{Na}+$ influx through the fusion pore. Nat Cell Biol 9:915922. CrossRef Medline

Guzman RE, Schwarz YN, Rettig J, Bruns D (2010) SNARE force synchronizes synaptic vesicle fusion and controls the kinetics of quantal synaptic transmission. J Neurosci 30:10272-10281. CrossRef Medline

Han J, Pluhackova K, Wassenaar TA, Böckmann RA (2015) Synaptobrevin transmembrane domain dimerization studied by multiscale molecular dynamics simulations. Biophys J 109:760-771. CrossRef Medline

Han J, Pluhackova K, Böckmann RA (2016) Exploring the formation and the structure of synaptobrevin oligomers in a model membrane. Biophys J 110:2004-2015. CrossRef Medline

Han X, Jackson MB (2005) Electrostatic interactions between the syntaxin membrane anchor and neurotransmitter passing through the fusion pore. Biophys J 88:L20-L22. CrossRef Medline

Han X, Wang CT, Bai J, Chapman ER, Jackson MB (2004) Transmembrane segments of syntaxin line the fusion pore of $\mathrm{Ca}^{2+}$-triggered exocytosis. Science 304:289-292. CrossRef Medline

Häusser M, Roth A (1997) Dendritic and somatic glutamate receptor channels in rat cerebellar Purkinje cells. J Physiol 501:77-95. CrossRef Medline

He L, Wu XS, Mohan R, Wu LG (2006) Two modes of fusion pore opening revealed by cell-attached recordings at a synapse. Nature 444:102-105. CrossRef Medline

Heckmann M, Dudel J (1997) Desensitization and resensitization kinetics of glutamate receptor channels from Drosophila larval muscle. Biophys J 72:2160-2169. CrossRef Medline

Hua SY, Charlton MP (1999) Activity-dependent changes in partial VAMP complexes during neurotransmitter release. Nat Neurosci 2:1078-1083. CrossRef Medline

Isaacson JS, Nicoll RA (1991) Aniracetam reduces glutamate receptor desensitization and slows the decay of fast excitatory synaptic currents in the hippocampus. Proc Natl Acad Sci U S A 88:10936-10940. CrossRef Medline

Ito I, Tanabe S, Kohda A, Sugiyama H (1990) Allosteric potentiation of quisqualate receptors by a nootropic drug aniracetam. J Physiol 424:533543. CrossRef Medline

Jackson MB (2007) In search of the fusion pore of exocytosis. Biophys Chem 126:201-208. CrossRef Medline

Jackson MB (2010) SNARE complex zipping as a driving force in the dilation of proteinaceous fusion pores. J Membr Biol 235:89-100. CrossRef Medline

Jahn R, Fasshauer D (2012) Molecular machines governing exocytosis of synaptic vesicles. Nature 490:201-207. CrossRef Medline

Jahn R, Scheller RH (2006) SNAREs: engines for membrane fusion. Nat Rev Mol Cell Biol 7:631-643. CrossRef Medline

Jun Y, Xu H, Thorngren N, Wickner W (2007) Sec18p and Vam7p remodel trans-SNARE complexes to permit a lipid-anchored R-SNARE to support yeast vacuole fusion. EMBO J 26:4935-4945. CrossRef Medline

Kessler JP (2013) Control of cleft glutamate concentration and glutamate spill-out by perisynaptic glia: uptake and diffusion barriers. PLoS One 8:e70791. CrossRef Medline

Khanin R, Parnas H, Segel L (1994) Diffusion cannot govern the discharge of neurotransmitter in fast synapses. Biophys J 67:966-972. CrossRef Medline

Klyachko VA, Jackson MB (2002) Capacitance steps and fusion pores of small and large-dense-core vesicles in nerve terminals. Nature 418:89-92. CrossRef Medline

Laage R, Langosch D (1997) Dimerization of the synaptic vesicle protein synaptobrevin (vesicle-associated membrane protein) II depends on specific residues within the transmembrane segment. Eur J Biochem 249: 540-546. CrossRef Medline

Laage R, Rohde J, Brosig B, Langosch D (2000) A conserved membranespanning amino acid motif drives homomeric and supports heteromeric assembly of presynaptic SNARE proteins. J Biol Chem 275:17481-17487. CrossRef Medline

Lawrence JJ, Brenowitz S, Trussell LO (2003) The mechanism of action of aniracetam at synaptic alpha-amino-3-hydroxy-5-methyl-4isoxazolepropionic acid (AMPA) receptors: indirect and direct effects on desensitization. Mol Pharmacol 64:269-278. CrossRef Medline

Lindau M, Almers W (1995) Structure and function of fusion pores in exocytosis and ectoplasmic membrane fusion. Curr Opin Cell Biol 7:509517. CrossRef Medline

Liu X, Porteous R, d'Anglemont de Tassigny X, Colledge WH, Millar R, Petersen SL, Herbison AE (2011) Frequency-dependent recruitment of fast amino acid and slow neuropeptide neurotransmitter release controls gonadotropin-releasing hormone neuron excitability. J Neurosci 31: 2421-2430. CrossRef Medline

Lloris-Garcerá P, Slusky JS, Seppälä S, Prieß M, Schäfer LV, von Heijne G (2013) In vivo Trp scanning of the small multidrug resistance protein EmrE confirms 3D structure models'. J Mol Biol 425:4642-4651. CrossRef Medline

Lomeli H, Mosbacher J, Melcher T, Höger T, Geiger JR, Kuner T, Monyer H, Higuchi M, Bach A, Seeburg PH (1994) Control of kinetic properties of AMPA receptor channels by nuclear RNA editing. Science 266:17091713. CrossRef Medline

McNew JA, Weber T, Parlati F, Johnston RJ, Melia TJ, Söllner TH, Rothman JE (2000) Close is not enough: SNARE-dependent membrane fusion 
requires an active mechanism that transduces force to membrane anchors. J Cell Biol 150:105-117. CrossRef Medline

Melia TJ, Weber T, McNew JA, Fisher LE, Johnston RJ, Parlati F, Mahal LK, Sollner TH, Rothman JE (2002) Regulation of membrane fusion by the membrane-proximal coil of the t-SNARE during zippering of SNAREpins. J Cell Biol 158:929-940. CrossRef Medline

Mohrmann R, de Wit H, Verhage M, Neher E, Sørensen JB (2010) Fast vesicle fusion in living cells requires at least three SNARE complexes. Science 330:502-505. CrossRef Medline

Monks SA, Needleman DJ, Miller C (1999) Helical structure and packing orientation of the S2 segment in the shaker K+ channel. J Gen Physiol 113:415-423. CrossRef Medline

Montecucco C, Schiavo G, Pantano S (2005) SNARE complexes and neuroexocytosis: how many, how close? Trends Biochem Sci 30:367-372. CrossRef Medline

Nielsen TA, DiGregorio DA, Silver RA (2004) Modulation of glutamate mobility reveals the mechanism underlying slow-rising AMPAR EPSCs and the diffusion coefficient in the synaptic cleft. Neuron 42:757-771. CrossRef Medline

Ninomiya Y, Kishimoto T, Yamazawa T, Ikeda H, Miyashita Y, Kasai H (1997) Kinetic diversity in the fusion of exocytotic vesicles. EMBO J 16: 929-934. CrossRef Medline

Otis TS, Wu YC, Trussell LO (1996a) Delayed clearance of transmitter and the role of glutamate transporters at synapses with multiple release sites. J Neurosci 16:1634-1644. CrossRef Medline

Otis T, Zhang S, Trussell LO (1996b) Direct measurement of AMPA receptor desensitization induced by glutamatergic synaptic transmission. J Neurosci 16:7496-7504. CrossRef Medline

Pawlu C, DiAntonio A, Heckmann M (2004) Postfusional control of quantal current shape. Neuron 42:607-618. CrossRef Medline

Pobbati AV, Stein A, Fasshauer D (2006) N- to C-terminal SNARE complex assembly promotes rapid membrane fusion. Science 313:673-676. CrossRef Medline

Raman IM, Trussell LO (1995) The mechanism of alpha-amino-3-hydroxy5-methyl-4-isoxazolepropionate receptor desensitization after removal of glutamate. Biophys J 68:137-146. CrossRef Medline

Roy R, Laage R, Langosch D (2004) Synaptobrevin transmembrane domain dimerization-revisited. Biochemistry 43:4964-4970. CrossRef Medline

Schmitz SK, Hjorth JJ, Joemai RM, Wijntjes R, Eijgenraam S, de Bruijn P, Georgiou C, de Jong AP, van Ooyen A, Verhage M, Cornelisse LN, Toonen RF, Veldkamp W (2011) Automated analysis of neuronal morphology, synapse number and synaptic recruitment. J Neurosci Methods 195:185-193. CrossRef Medline

Scimemi A, Beato M (2009) Determining the neurotransmitter concentration profile at active synapses. Mol Neurobiol 40:289-306. CrossRef Medline

Shi L, Shen QT, Kiel A, Wang J, Wang HW, Melia TJ, Rothman JE, Pincet F
(2012) SNARE proteins: one to fuse and three to keep the nascent fusion pore open. Science 335:1355-1359. CrossRef Medline

Sinha R, Ahmed S, Jahn R, Klingauf J (2011) Two synaptobrevin molecules are sufficient for vesicle fusion in central nervous system synapses. Proc Natl Acad Sci U S A 108:14318-14323. CrossRef Medline

Sørensen JB, Wiederhold K, Müller EM, Milosevic I, Nagy G, de Groot BL, Grubmüller H, Fasshauer D (2006) Sequential N- to C-terminal SNARE complex assembly drives priming and fusion of secretory vesicles. EMBO J 25:955-966. CrossRef Medline

Stiles JR, Van Helden D, Bartol TM Jr, Salpeter EE, Salpeter MM (1996) Miniature endplate current rise times $<100 \mu$ s from improved dual recordings can be modeled with passive acetylcholine diffusion from a synaptic vesicle. Proc Natl Acad Sci U S A 93:5747-5752. CrossRef Medline

Taylor WR, Chen E, Copenhagen DR (1995) Characterization of spontaneous excitatory synaptic currents in salamander retinal ganglion cells. J Physiol 486:207-221. CrossRef Medline

Trussell LO, Fischbach GD (1989) Glutamate receptor desensitization and its role in synaptic transmission. Neuron 3:209-218. CrossRef Medline

van den Bogaart G, Holt MG, Bunt G, Riedel D, Wouters FS, Jahn R (2010) One SNARE complex is sufficient for membrane fusion. Nat Struct Mol Biol 17:358-364. CrossRef Medline

Verhage M, McMahon HT, Ghijsen WE, Boomsma F, Scholten G, Wiegant VM, Nicholls DG (1991) Differential release of amino acids, neuropeptides, and catecholamines from isolated nerve terminals. Neuron 6:517524. CrossRef Medline

Vyklicky L Jr, Patneau DK, Mayer ML (1991) Modulation of excitatory synaptic transmission by drugs that reduce desensitization at AMPA/kainate receptors. Neuron 7:971-984. CrossRef Medline

Wahl LM, Pouzat C, Stratford KJ (1996) Monte Carlo simulation of fast excitatory transmission at a hippocampal synapse. J Neurophysiol 75: 597-608. CrossRef Medline

Wu XS, Xue L, Mohan R, Paradiso K, Gillis KD, Wu LG (2007) The origin of quantal size variation: vesicular glutamate concentration plays a significant role. J Neurosci 27:3046-3056. CrossRef Medline

Xu H, Zick M, Wickner WT, Jun Y (2011) A lipid-anchored SNARE supports membrane fusion. Proc Natl Acad Sci U S A 108:17325-17330. CrossRef Medline

Xu T, Rammner B, Margittai M, Artalejo AR, Neher E, Jahn R (1999) Inhibition of SNARE complex assembly differentially affects kinetic components of exocytosis. Cell 99:713-722. CrossRef Medline

Zhang Z, Zhang Z, Jackson MB (2010) Synaptotagmin IV modulation of vesicle size and fusion pores in PC12 cells. Biophys J 98:968-978. CrossRef Medline

Zhao WD, Hamid E, Shin W, Wen PJ, Krystofiak ES, Villarreal SA, Chiang HC, Kachar B, Wu LG (2016) Hemi-fused structure mediates and controls fusion and fission in live cells. Nature 534:548-552. CrossRef Medline 